\title{
Determination of fumonisins B1 and B2 in Portuguese maize and maize-based samples by HPLC with fluorescence detection
}

Received: 18 November 2005 / Revised: 19 December 2005 / Accepted: 21 December 2005 / Published online: 8 February 2006 (C) Springer-Verlag 2006

\begin{abstract}
Fumonisins $\mathrm{B}_{1}\left(\mathrm{FB}_{1}\right)$ and fumonisin $\mathrm{B}_{2}\left(\mathrm{FB}_{2}\right)$ are the main members of a family of mycotoxins produced by Fusarium verticillioides, Fusarium proliferatum, and other fungi species of the section Liseola. The present work shows the results of comparative studies using two different procedures for the analysis of fumonisins in maize and maize-based samples. The studied analytical methods involve extraction with methanol/water, dilution with PBS, and clean-up through immunoaffinity columns. Two reagents (o-phthaldialdehyde and naphthalene-2,3-dicarboxaldehyde) were studied for formation of fluorescent derivatives. The separation and identification were carried out by high-performance liquid chromatography with fluorescence detection. The optimized method for analysis of fumonisins in maize involved extraction with methanol/ water (80:20), clean-up with an immunoaffinity column, and derivatization with naphthalene-2,3-dicarboxaldehyde (NDA). The limit of detection was $20 \mu \mathrm{g} \mathrm{kg}^{-1}$ for $\mathrm{FB}_{1}$ and $15 \mu \mathrm{g} \mathrm{kg}^{-1}$ for $\mathrm{FB}_{2}$. Recoveries of $\mathrm{FB}_{1}$ and $\mathrm{FB}_{2}$ ranged from $79 \%$ to $99.6 \%$ for maize fortified at $150 \mathrm{\mu g} \mathrm{kg}^{-1}$ and $200 \mu \mathrm{g} \mathrm{kg}^{-1}$, respectively, with within-day RSDs of 3.0 and $2.7 \%$. The proposed method was applied to 31 samples, and the presence of fumonisins was found in 14 samples at concentrations ranging from 113 to $2,026 \mu \mathrm{g} \mathrm{kg}^{-1}$. The estimated daily intake of fumonisins was $0.14 \mu \mathrm{g} \mathrm{kg}^{-1}$ body weight per day.
\end{abstract}

Keywords Fumonisins $\mathrm{B}_{1}$ and $\mathrm{B}_{2} \cdot$ Maize Maize derivatives $\cdot$ HPLC

\section{Introduction}

Fumonisins (FBs) are a group of toxins comprising fumonisins $\mathrm{B}_{1}\left(\mathrm{FB}_{1}\right), \mathrm{B}_{2}\left(\mathrm{FB}_{2}\right)$, and $\mathrm{B}_{3}\left(\mathrm{FB}_{3}\right)$. FBs are

C. M. Lino $(\bowtie) \cdot$ L. J. G. Silva $\cdot$ A. L. S. Pena $\cdot$ M. I. Silveira Group of Bromatology - CEF, Faculty of Pharmacy,

University of Coimbra,

3000-295 Coimbra, Portugal

e-mail: cmlino@ci.uc.pt structurally analogous to sphingosine [1] and are mainly yielded by Fusarium verticillioides, Fusarium proliferatum, and other fungi species of the section Liseola [2]. $\mathrm{FB}_{1}$ is the most abundant and the most toxic fumonisin, followed by $\mathrm{FB}_{2}$ [3]. FBs has been linked with an increased risk of oesophageal cancer in humans in the Transkei region of South Africa and China [1] and are possibly connected with neural tube defects (NTD) in South Texas, USA [4]. FB 1 is classified by International Agency for Research on Cancer (IARC) as possibly carcinogenic in humans (Group 2B) [5].

The wide geographical distribution of the fumonisinproducing maize pathogen $F$. verticillioides and its endophytic nature in maize have resulted in fumonisins occurring naturally in maize or products containing maize worldwide [6]. High levels of fumonisins in maize have been found in many countries, including Morocco [7], Brasil [8], Nigeria [9], and South Africa [10]. In Europe sporadic studies have been recently published [11].

Maize (Zea mays L.) is one of the most important crops in Portugal, representing a maize area and production of 126,000 ha and 665,000 Mt, respectively [12].

In Portugal, a single investigation of $\mathrm{FB}_{1}$ and $\mathrm{FB}_{2}$ in nine naturally contaminated maize hybrids, originating from the 1992 crop from the Agricultural School of Coimbra, was reported in international references, and revealed a high frequency of contamination, $100 \%$ [13].

Since the discovery of these mycotoxins and their characterization in 1988, there has been significant progress in the analytical methods used for their detection [14].

Recently, Lino et al. [15] reviewed the analytical methodology available for the determination of fumonisins in foods. These methods generally involve liquid extraction, with mixtures of polar solvents, such as methanol/ water [16, 17], acetonitrile/water [18], methanol/acetonitrile/water [19], and acetonitrile/ $\mathrm{NaH}_{2} \mathrm{PO}_{4}$ [20]. A clean-up procedure is frequently applied that usually employs solidphase extraction (SPE) columns such as with reversedphase columns $[18,20]$, strong anion exchange columns (SAXs) $[8,21]$, and immunoaffinity columns (IACs) [17, $22]$ that present higher specificity. Different derivatization 
reagents have been reported, namely, $o$ - phthaldialdehyde (OPA) - the most used [8, 9, 21], naphthalene-2,3-dicarboxaldehyde (NDA) [19, 20, 23], and 4-fluoro-7-nitrobenzofurazan (NBD-F) [24]. Detection and quantification have preferentially been performed using HPLC with fluorescence or mass spectrometry detection $[8,9,21,22,25-28]$ although other chromatographic, electrophoretic, and immunological methods have been reported [15].

The objective in the present study was to optimize a sensitive and accurate method for determination of FBs in maize and derivatives by HPLC with pre-column derivatization and fluorescence detection, and to provide data on the occurrence of $\mathrm{FB}_{1}$ and $\mathrm{FB}_{2}$ in 31 maize and maize product samples consumed in central Portugal. The method was useful for assessing the potential contribution of dietary exposure to maize products in Portuguese consumers.

\section{Materials and methods}

Apparatus and chromatographic conditions

The high-performance liquid chromatography (HPLC) apparatus used consisted of a Gilson 307 pump (Gilson Medical Electronics, Villiers-le-Bel, France), one 50- $\mu \mathrm{L}$ Rheodyne 7125 injector (Cotati, CA, USA), a 5- $\mu \mathrm{m} \mathrm{C}_{18}$ Nucleosil 120 guard column KS (30 $\mathrm{mm} \times 4$-mm i.d.), and a 5- $\mu \mathrm{m} \mathrm{C}_{18}$ Nucleosil 120 column $(250 \mathrm{~mm} \times 4.6-\mathrm{mm}$ i.d. $)$. A Perkin Elmer LS45 spectrofluorimeter (Perkin Elmer, Beaconsfield, UK) operating at an excitation wavelength of $420 \mathrm{~nm}$ and an emission wavelength of $500 \mathrm{~nm}$ was used.

The results were recorded on a 3990 integrator (HewlletPackard, Philadelphia, PA). The mobile phase (acetonitrile/ water/acetic acid 61:38:1 v/v/v) was maintained at a flow rate of $1 \mathrm{~mL} \mathrm{~min}^{-1}$.

Isocratic analysis under the conditions described above allowed the elution of $\mathrm{FB}_{1}$ and $\mathrm{FB}_{2}$ with a retention time of about $7.36 \mathrm{~min}$ and $13.34 \mathrm{~min}$, respectively, when NDA derivatization was used.

A Meditronic S-599 centrifuge (Selecta, Barcelona, Spain), Retsh vortex mixer (Haan, Germany), and a Sonorex RK 100 ultrasonic bath (Berlin, Germany) were also used.

\section{Chemicals}

HPLC-grade acetonitrile (ACN) and methanol were purchased from Carlo Erba (Milan, Italy). Acetic acid, hydrochloride acid, sodium hydroxide, potassium chloride, potassium dihydrogen phosphate, anhydrous disodium hydrogen phosphate, potassium cyanide, sodium tetraborate, and sodium chloride were obtained from Merck (Darmstadt, Germany). Water was prepared from a Milli Q system (Millipore, Bedford, MA, USA). $\mathrm{FB}_{1}$ and $\mathrm{FB}_{2}$ standards, naphthalene-2,3-dicarboxaldehyde (NDA), and 2-mercaptoethanol (MCE) were obtained from Sigma Chemicals Co (St. Louis, USA). o-Phthaldialdehyde (OPA) was obtained from Carlo Erba (Milan, Italy).
FumoniTest immunoaffinity columns were from Vicam (Watertown, USA).

Phosphate buffer solution (PBS) was prepared from $0.2 \mathrm{~g}$ potassium chloride, $0.2 \mathrm{~g}$ potassium dihydrogen phosphate, $1.2 \mathrm{~g}$ anhydrous disodium hydrogen phosphate, and $8.0 \mathrm{~g}$ sodium chloride to $990 \mathrm{~mL}$ distilled water, adjusted to $\mathrm{pH}$ 7.0 with $25 \% \mathrm{HCl}$, and the solution was made up to $1 \mathrm{~L}$.

The OPA derivatization reagent was prepared by mixing $40 \mathrm{mg}$ OPA, $1 \mathrm{~mL}$ of methanol, $5 \mathrm{~mL}$ of a $0.1 \mathrm{M}$ aqueous sodium tetraborate, and $50 \mu \mathrm{L}$ of 2 -mercaptoethanol. The naphthalene-2,3-dicarboxaldehyde (NDA) solution was prepared at $0.5 \mathrm{mg} \mathrm{mL}^{-1}$ in acetonitrile. The potassium cyanide was prepared at $0.13 \mathrm{mg} \mathrm{mL}^{-1} ; 0.05 \mathrm{M}$ sodium borate solution was adjusted to $\mathrm{pH} 9.5$ with $1 \mathrm{~N} \mathrm{NaOH}$.

The mobile phase consisted of acetonitrile/water/acetic acid $(61: 38: 1 \mathrm{v} / \mathrm{v} / \mathrm{v})$.

The stock solutions, prepared in the $\mathrm{FB}_{1}$ and $\mathrm{FB}_{2}$ vials purchased from Sigma Chemicals, were made in $1 \mathrm{~mL}$ acetonitrile/water (50:50) at $1,000 \mu \mathrm{g} \mathrm{mL}{ }^{-1}$. Intermediate solutions were prepared at $50 \mu \mathrm{g} \mathrm{mL}^{-1}$, diluting $250 \mu \mathrm{L}$ of stock solution with $5 \mathrm{~mL}$ acetonitrile/water $(50: 50)$. For fortification assays, one work solution was prepared with acetonitrile/water (50:50) at $5 \mu \mathrm{g} \mathrm{mL} \mathrm{m}^{-1}$ for both fumonisins. For determination of the calibration curve, two work solutions were prepared at $50 \mu \mathrm{g} \mathrm{mL}^{-1}$ and $5 \mu \mathrm{g} \mathrm{mL}^{-1}$. The others were prepared by diluting one of these solutions at the following concentrations: $5.0,2.5,1.0,0.5$, and $0.25 \mu \mathrm{g} \mathrm{mL}^{-1}$. All solutions were kept in amber flasks to protect from light.

\section{Sampling}

A total of 31 samples were purchased in commercially available sizes from March to July 2005 at shops, health food stores, and supermarkets located in the city of Coimbra. The following commodities were collected: yellow maize $(n=9)$, white maize $(n=2)$, maize flour $(n=3)$, maize semolina $(n=3)$, maize starch $(n=3)$, sweet maize $(n=11)$. Samples, except for maize flour, maize semolina, and maize starch, were finely milled in the switching apparatus.

\section{Recoveries}

The recoveries of fumonisins from maize and maize starch were determined by spiking the ground sample of each food (three replications) with known amounts of fumonisins at final concentrations between $100 \mu \mathrm{g} \mathrm{kg}^{-1}$ and $250 \mu \mathrm{g} \mathrm{kg}^{-1}$.

\section{Extraction and clean-up procedures}

\section{Method A}

Ground samples $(50 \mathrm{~g})$ were mixed with $5 \mathrm{~g} \mathrm{NaCl}$ and placed into a blender jar. One hundred $\mathrm{mL} \mathrm{CH}_{3} \mathrm{OH} / \mathrm{H}_{2} \mathrm{O}$ 


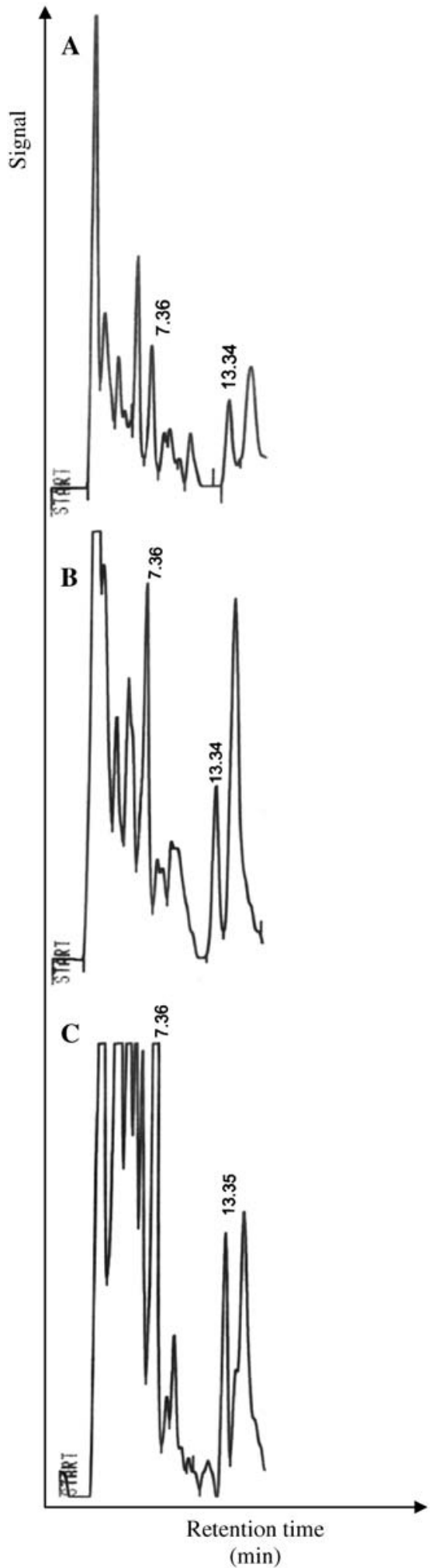

Fig. 1 Liquid chromatography spectrofluorimetric chromatogram of fumonisin $\mathrm{B}_{1}$ and $\mathrm{B}_{2}$ standard (a) (retention time 7.36 and 13.34 min for $\mathrm{FB}_{1}$ and $\mathrm{FB}_{2}$, respectively), one fortified sample at $250 \mu \mathrm{g} \mathrm{kg}^{-1}$ for $\mathrm{FB}_{1}$ and $200 \mu \mathrm{g} \mathrm{kg}-1$ for $\mathrm{FB}_{2}$ (b), and one contaminated sample (c), obtained using the optimized method
$(80: 20 \mathrm{v} / \mathrm{v})$ was added. The mixture was blended at high speed for 5 min, filtered through a Whatman $\mathrm{N}^{\circ} 1$ filter paper, and collected in a clean vessel. Ten $\mathrm{mL}$ of filtered extract was transferred to another vessel and eluted with $40 \mathrm{~mL}$ PBS. The extract was filtered through microfiber filter (Whatman 934-AH, $110 \mathrm{~mm}$ ). Ten $\mathrm{mL}$ was added to a FumoniTest IAC attached onto a vacuum manifold. The column was washed with $10 \mathrm{~mL}$ PBS, and fumonisins were eluted with $1.5 \mathrm{~mL}$ methanol. After evaporation under a gentle nitrogen stream at $60^{\circ} \mathrm{C}$, the residue was redissolved in $50 \mu \mathrm{L}$ methanol/water $(50: 50 \mathrm{v} / \mathrm{v})$.

\section{Method B}

Ground samples $(25 \mathrm{~g})$ were extracted with $40 \mathrm{~mL}$ $\mathrm{CH}_{3} \mathrm{OH} / \mathrm{H}_{2} \mathrm{O}(80: 20 \mathrm{v} / \mathrm{v})$, centrifuged for $15 \mathrm{~min}$ at $2,500 \mathrm{~g}$. The remaining solid was extracted twice with 30 $\mathrm{mL}$ each. The three extracts were combined and filtrated (Whatman $\mathrm{N}^{\circ} 1$ paper). For clean-up, $10 \mathrm{~mL}$ of filtrate diluted with $40 \mathrm{~mL}$ phosphate-buffered saline was filtrated through glass microfiber. Twenty $\mathrm{mL}$ was added to a FumoniTest IAC attached onto a vacuum manifold. The column was washed with $10 \mathrm{~mL}$ PBS, and fumonisins were eluted with $2 \times 1.5 \mathrm{~mL}$ methanol. After evaporation under a gentle nitrogen stream at $60^{\circ} \mathrm{C}$, the residue was reconstituted with $50 \mu \mathrm{L}$ methanol/water $(50: 50 \mathrm{v} / \mathrm{v})$.

\section{Derivatization}

Five hundred microliter $0.05 \mathrm{M}$ sodium borate buffer $(\mathrm{pH}$ 9.5 adjusted with $1 \mathrm{~N} \mathrm{NaOH}$ ), $500 \mu \mathrm{L}$ sodium cyanide reagent, and $150 \mu \mathrm{L}$ NDA reagent $\left(0.5 \mathrm{mg} \mathrm{mL}^{-1} \mathrm{ACN}\right)$ were added to the reconstituted residue. The mixture was heated for $15 \mathrm{~min}$ at $60^{\circ} \mathrm{C}$ in a heating bath and cooled to room temperature.

\section{Results and discussion}

The calibration curves were obtained using the linear leastsquares regression procedure for the peak area plotted versus the concentration. The linearity for $\mathrm{FB}_{1}$ and $\mathrm{FB}_{2}$, in the working standard solutions at four determinations of

Table 1 Comparison of different chromatographic conditions with $\mathrm{OPA}$ at $\lambda_{\mathrm{exc}}=335 \mathrm{~nm}$ and $\lambda_{\mathrm{em}}=440 \mathrm{~nm}$

\begin{tabular}{lcll}
\hline $\begin{array}{l}\text { Volumes of } \\
\text { OPA }(\mu \mathrm{L})\end{array}$ & $\begin{array}{l}\text { Quantity of } \\
\text { standard }(\mathrm{ng})\end{array}$ & Mobile phase & $\begin{array}{l}\text { Flow rate } \\
\left.(\mathrm{mL} \mathrm{min})^{-1}\right)\end{array}$ \\
\hline 100 & 1,000 & $\begin{array}{r}\mathrm{A}=\mathrm{ACN} / \mathrm{H}_{2} \mathrm{O} / \mathrm{CH}_{3} \\
\mathrm{COOH}(49.5: 49.5: 1.0)\end{array}$ \\
100 & 50 & $\begin{array}{r}\mathrm{B}=\mathrm{ACN} / \mathrm{H}_{2} \mathrm{O} / \mathrm{CH}_{3} \\
\mathrm{COOH}(59.0: 40.0: 1.0)\end{array}$ \\
& \multicolumn{3}{c}{1.0} \\
\hline \multicolumn{3}{c}{} \\
\hline \multicolumn{3}{c}{}
\end{tabular}


Table 2 Comparison of different chromatographic conditions with $\mathrm{NDA}$ at $\lambda_{\mathrm{exc}}=420 \mathrm{~nm}$ and $\lambda_{\mathrm{em}}=500 \mathrm{~nm}$

\begin{tabular}{ll}
\hline Mobile phase & $\begin{array}{l}\text { Flow rate } \\
\left(\mathrm{mL} \mathrm{min}{ }^{-1}\right)\end{array}$ \\
\hline $\mathrm{A}=65 \% \mathrm{ACN} / \mathrm{CH}_{3} \mathrm{COOH}(99: 1)+35 \% \mathrm{H}_{2} \mathrm{O} /$ & 1.0 \\
$\mathrm{CH}_{3} \mathrm{COOH}(99: 1)$ & \\
$\mathrm{B}=\mathrm{ACN} / \mathrm{H}_{2} \mathrm{O} / \mathrm{CH}_{3} \mathrm{COOH}(63: 36: 1)$ & 1.0 \\
$\mathrm{C}=\mathrm{ACN} / \mathrm{H}_{2} \mathrm{O} / \mathrm{CH}_{3} \mathrm{COOH}(60: 39: 1)$ & 1.0 \\
$\mathrm{D}=\mathrm{ACN} / \mathrm{H}_{2} \mathrm{O} / \mathrm{CH}_{3} \mathrm{COOH}(59: 40: 1)$ & 0.9 \\
$\mathrm{E}=\mathrm{ACN} / \mathrm{H}_{2} \mathrm{O} / \mathrm{CH}_{3} \mathrm{COOH}(62: 40: 1)$ & 1.0 \\
$\mathrm{~F}=\mathrm{ACN} / \mathrm{H}_{2} \mathrm{O} / \mathrm{CH}_{3} \mathrm{COOH}(61: 38: 1)$ & 1.0 \\
\hline
\end{tabular}

five concentration levels, between 0.25 and $5.0 \mu \mathrm{g} \mathrm{mL}^{-1}$, which corresponds to $0.52 \mathrm{ng}$ and $10.4 \mathrm{ng}$ injected, was good as shown by the fact that the correlation coefficients $\left(r^{2}\right)$ were 0.984 and 0.994 for $\mathrm{FB}_{1}$ and $\mathrm{FB}_{2}$, respectively.

Figure 1 shows the HPLC spectrofluorimeter chromatograms of the FBs standard, one sample and one sample fortified using method $\mathrm{B} . \mathrm{FB}_{1}$ and $\mathrm{FB}_{2}$ standards were initially analyzed using pre-column derivatization with $o$-phthaldialdehyde (OPA) and reversed-phase HPLC separation with an isocratic elution followed by fluorescence detection. Different chromatographic conditions were used (Table 1). When mobile phase A was used, according to Bittencourt et al. [8], long retention times were obtained: 12.57 for $\mathrm{FB}_{1}$ and 33.10 for $\mathrm{FB}_{2}$. The proportion of acetonitrile was increased and the retention times decreased to 5.49 and 10.09 for $\mathrm{FB}_{1}$ and $\mathrm{FB}_{2}$, respectively.

Several fluorescent derivatives have been reported. Although OPA-MCE is currently the most commonly used derivatization reagent it has the disadvantage of exhibiting time-dependent degradation, leading to the rapid decay of fluorescence after derivatization [29-31]. This disadvantage was overcome by the use of naphthalene-2,3dicarboxaldehyde (NDA) that has been reported in several studies [19-21, 29, 32].

Derivatization reaction with NDA was performed according to the methods of $\mathrm{Chu}$ and $\mathrm{Li}$ [32] and Bennett and Richard [29], with some modifications. The best conditions were obtained using $150 \mu \mathrm{L}$ of derivatization reagent and replacing the redissolution of the residue by $50 \mu \mathrm{L}$ methanol/water (50:50). Different mobile phases were also experimented (see Table 2). The best results were obtained with $\mathrm{ACN} / \mathrm{H}_{2} \mathrm{O} / \mathrm{CH}_{3} \mathrm{COOH}(61: 38: 1 \mathrm{v} / \mathrm{v} / \mathrm{v})$.

NDA with $\mathrm{KCN}$ formed a highly fluorescent derivative which was relatively stable over $24 \mathrm{~h} \mathrm{[30]}$.

Table 3 Stability of NDA fluorescent derivatives (ng and \%)

\begin{tabular}{ccccccc}
\hline Fumonisins & 1 day & \multicolumn{3}{c}{1 day } & \multicolumn{3}{c}{8 days } \\
\hline $\mathrm{FB}_{1}$ ng (\%) & 1.04 & 1.15 & 2.08 & 1.65 & 2.08 & 1.41 \\
& $(100)$ & $(110)$ & $(100)$ & $(79.4)$ & $(100)$ & $(67.7)$ \\
$\mathrm{FB}_{2}$ ng (\%) & 1.04 & 0.66 & 2.08 & 1.56 & 2.08 & 0.67 \\
& $(100)$ & $(62.9)$ & $(100)$ & $(75.0)$ & $(100)$ & $(32.1)$ \\
\hline
\end{tabular}

Studies on the stability of NDA fluorescent derivatives were performed with the same standard, after $24 \mathrm{~h}$ and 8 days (Table 3 ). This study demonstrated that after 1 day, the stability of NDA-FB 1 and NDA-FB ${ }_{2}$ decreased slightly. However, a minor increase in the percentage of NDA-FB ${ }_{1}$ was observed, as reported by Bennett and Richard [29]. After 8 days, the loss of $\mathrm{FB}_{2}$ was more significant than that of $\mathrm{FB}_{1}$. NDA-FBs derivatives have higher stability than OPA derivatives, as reported by Sydenham et al. [33] and Williams et al. [31]. NDA also tends to give higher values at lower toxin levels present in maize samples [32].

The methanol/water $(80: 20 \mathrm{v} / \mathrm{v})$, previously applied by Cortez-Rocha et al. [17] used as an extraction solvent, was successfully used to extract fumonisins from maize and maize-based products.

The accuracy was determined by calculating the mean recovery values used for each fortification level (Table 4). The recovery values for $\mathrm{FB}_{1}$, using the method $\mathrm{B}$, were $79.0 \%$ and $98.5 \%$ for fortification levels at 150 and $250 \mu \mathrm{g} \mathrm{kg}^{-1}$, respectively. For $\mathrm{FB}_{2}$, recovery values were $98.4 \%$ and $99.6 \%$ for fortification levels at 100 and $200 \mu \mathrm{g} \mathrm{kg}^{-1}$, respectively. The precision was calculated from intraday repeatability $(n=3)$ and interday repeatability (3 days). For $\mathrm{FB}_{1}$, the intraday repeatability obtained oscillated between 3.0 and $3.9 \%$ for fortification levels at 150 and $250 \mu \mathrm{g} \mathrm{kg}^{-1}$, respectively. For $\mathrm{FB}_{2}$, intraday repeatability was 2.7 and $10.4 \%$ at 200 and $100 \mu \mathrm{g} \mathrm{kg}^{-1}$, respectively. The 3 -day repeatability $(n=9)$ obtained for $\mathrm{FB}_{1}$, oscillated between 10.0 and $14.0 \%$ for fortification levels at 150 and $250 \mu \mathrm{g} \mathrm{kg}^{-1}$, respectively. For $\mathrm{FB}_{2}$ the corresponding values were 15.1 and $15.8 \%$ at 200 and $100 \mu \mathrm{g} \mathrm{kg}^{-1}$, respectively.

These values were lower, about $50 \%$, using method A either with normal filtration $[19,22]$ or vacuum filtration. The filtration process therefore required modification, since the slurry produced after extraction clogged the Whatman $\mathrm{N}^{\circ} 1$ filter paper, with or without vacuum, leading to losses. Due to the characteristics of the sample, an efficient process for separating the matrix residue from the solvent extract was essential. Centrifugation was crucial to improve this step [34]. Moreover, the time expended when method B was applied was much lower. The centrifugation step allowed good separation between sample residue and extraction solution when $2,500 \mathrm{~g}$ was applied in contrast to what happened with $500 \mathrm{~g}$ and $1,000 \mathrm{~g}$. Attempts were made to optimize the analytical

Table 4 Accuracy and intra-assay validation results $(n=3)$ and interassay $(n=9)$ obtained with the optimized method

\begin{tabular}{lllll}
\hline Fumonisins & $\begin{array}{l}\text { Fortification } \\
\text { level }\left(\mu \mathrm{g} \mathrm{kg}^{-1}\right)\end{array}$ & $\begin{array}{l}\text { Recovery } \\
\text { mean }(\%)\end{array}$ & $\begin{array}{l}\text { RSD } \\
\text { within-day } \\
(\%)\end{array}$ & $\begin{array}{l}\text { RSD } \\
\text { between-day } \\
(\%)\end{array}$ \\
\hline $\mathrm{FB}_{1}$ & 150 & 79.0 & 3.0 & 10.0 \\
& 250 & 98.5 & 3.9 & 14.0 \\
$\mathrm{FB}_{2}$ & 100 & 98.4 & 10.4 & 15.8 \\
& 200 & 99.6 & 2.7 & 15.1 \\
\hline
\end{tabular}


methodology. Extraction of $25 \mathrm{~g}$ of a contaminated sample, spiked with $100 \mu \mathrm{g} \mathrm{kg}^{-1}$ of $\mathrm{FB}_{1}$ and $\mathrm{FB}_{2}$, centrifuging twice using $50 \mathrm{~mL}$ of extraction solvent, resulted in recoveries of $61.5 \%$ for $\mathrm{FB}_{1}$ and $95.6 \%$ for $\mathrm{FB}_{2}$. As the result obtained for $\mathrm{FB}_{1}$ was low, centrifugation was tried three times, and FBs were eluted from IAC twice with $1.5 \mathrm{~mL}$ methanol.

The limit of detection obtained using the NDA derivatization procedure, at a signal-to-noise ratio of $3: 1$, was $20 \mu \mathrm{g} \mathrm{kg}^{-1}$ for $\mathrm{FB}_{1}$ and $15 \mu \mathrm{g} \mathrm{kg}^{-1}$ for $\mathrm{FB}_{2}$.

\section{Application to real samples}

The method B was successfully applied to 31 samples of maize and maize-based products, and the presence of FBs was verified in 14 samples $(45 \%)$. The analyzed samples revealed high contamination levels, between nd and $1,569 \mu \mathrm{g} \mathrm{kg}^{-1}$ for $\mathrm{FB}_{1}$ and between nd and $457 \mu \mathrm{g} \mathrm{kg}^{-1}$ for $\mathrm{FB}_{2}$. In all groups of studied commodities, the mean concentration of $\mathrm{FB}_{2}$ is lower than $\mathrm{FB}_{1}$ (Table 5), which is usual in other studies $[11,35]$.

In our study, $67 \%$ of yellow maize and $100 \%$ of with maize samples (Table 5), which corresponds to $72.7 \%$ for all maize samples, were contaminated with FBs. These results are according to the only known study in Portugal for $\mathrm{FB}_{1}$ and $\mathrm{FB}_{2}$ in nine naturally contaminated maize hybrids, originating from the 1992 crop from the Agricultural School of Coimbra [13], which presented one incidence of $100 \%$. The mean concentrations in the present study for the totality of maize samples were $329 \mu \mathrm{g} \mathrm{kg}^{-1}$ for $\mathrm{FB}_{1}$ and $131 \mu \mathrm{g} \mathrm{kg}^{-1}$ for $\mathrm{FB}_{2}$, which are much lower when compared to the studies in Portuguese maize samples in 1992: $1,031 \mu \mathrm{g} \mathrm{kg}^{-1}$ for $\mathrm{FB}_{1}$ and $1,077 \mu \mathrm{g} \mathrm{kg}^{-1}$ for $\mathrm{FB}_{2}$ [13].

White maize samples, used for the preparation of cachupa, a traditional dish from Cabo Verde, presented higher levels of both fumonisins than yellow samples, $638 \mu \mathrm{g} \mathrm{kg}^{-1}$ versus $421 \mu \mathrm{g} \mathrm{kg}^{-1}$.

The average contamination levels found in maize samples, $329 \mu \mathrm{g} \mathrm{kg}^{-1}$ for $\mathrm{FB}_{1}$ and $131 \mu \mathrm{g} \mathrm{kg}^{-1}$ for $\mathrm{FB}_{2}$, are lower than those reported in Spain $\left(4,800 \mu \mathrm{g} \mathrm{kg}^{-1}\right.$ for $\mathrm{FB}_{1}$ and $1,900 \mu \mathrm{g} \mathrm{kg}^{-1}$ for $\left.\mathrm{FB}_{2}\right)$, UK $\left(3,046 \mu \mathrm{g} \mathrm{kg}^{-1}\right.$ for $\mathrm{FB}_{1}$ and $1,268 \mu \mathrm{g} \mathrm{kg}^{-1}$ for $\left.\mathrm{FB}_{2}\right)$, and Morocco $\left(1,930 \mu \mathrm{g} \mathrm{kg}^{-1}\right.$ for $\left.\mathrm{FB}_{1}\right)[36,35,7]$. However the percentage of positive samples in our study (72.7\%) is similar to that reported in Spain (87.3\%). In Nigeria similar levels of contamination have been reported $\left(495 \mu \mathrm{g} \mathrm{kg}^{-1}\right.$ for $\mathrm{FB}_{1}$ and $114 \mu \mathrm{g} \mathrm{kg}^{-1}$ for $\left.\mathrm{FB}_{2}\right)[9]$.

Maize flour samples presented the highest mean concentration of $\mathrm{FB}_{1}$ contamination, $822 \mu \mathrm{g} \mathrm{kg}{ }^{-1}$. $\mathrm{FB}_{2}$ presented a mean value of $173 \mu \mathrm{g} \mathrm{kg}^{-1}$. Higher values have been reported in France $\left(1,113 \mu \mathrm{g} \mathrm{kg}^{-1}\right.$ for $\left.\mathrm{FB}_{1}\right)$ [25], Italy $\left(\mathrm{FB}_{1}\right.$ ranged from 10 to $2,870 \mu \mathrm{g} \mathrm{kg}^{-1}$ and $\mathrm{FB}_{2}$ from 10 to $\left.420 \mu \mathrm{g} \mathrm{kg}^{-1}\right)$ [26], and Brazil $\left(2,100 \mu \mathrm{g} \mathrm{kg}^{-1}\right.$ for $\mathrm{FB}_{1}$ and $700 \mu \mathrm{g} \mathrm{kg}^{-1}$ for $\mathrm{FB}_{2}$ ) [8], whereas in Argentina the mean contamination of $\mathrm{FB}_{1}$ and $\mathrm{FB}_{2}$ were lower: $358 \mu \mathrm{g} \mathrm{kg}$ and $122 \mu \mathrm{g} \mathrm{kg}^{-1}$, respectively [37].

Results obtained for $\mathrm{FB}_{1}\left(118 \mu \mathrm{g} \mathrm{kg}{ }^{-1}\right)$ and $\mathrm{FB}_{2}$ (nd) in maize semolina are in agreement with those reported by

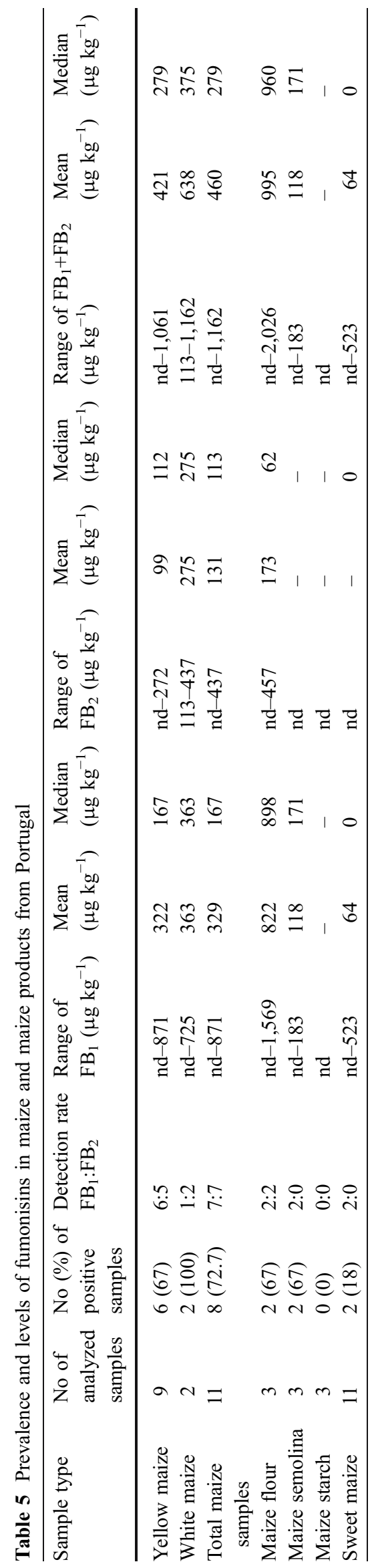


Piñeiro et al. [38] in Uruguay $\left(105 \mu \mathrm{g} \mathrm{kg}^{-1}\right.$ for $\mathrm{FB}_{1}$ and nd for $\left.\mathrm{FB}_{2}\right)$, Pittet et al. [39] in Switzerland $\left(260 \mu \mathrm{g} \mathrm{kg}^{-1}\right.$ for $\mathrm{FB}_{1}$ and $100 \mu \mathrm{g} \mathrm{kg}^{-1}$ for $\mathrm{FB}_{2}$ ), and Broggi et al. [37] in Argentina $\left(135 \mu \mathrm{g} \mathrm{kg}^{-1}\right.$ for $\mathrm{FB}_{1}$ and $39.1 \mu \mathrm{g} \mathrm{kg}^{-1}$ for $\mathrm{FB}_{2}$ ).

Fumonisins were not detected in maize starch. Piñeiro et al. [39] detected neither $\mathrm{FB}_{1}$ nor $\mathrm{FB}_{2}$ in the analyzed maize starch samples from Uruguay. This fact can be explained by the wet-milling process that leads to the migration of fumonisins into aqueous solutions during steeping [6].

Sweet maize samples presented the lowest contamination, $64 \mu \mathrm{g} \mathrm{kg}^{-1}$ in $18 \%$ of the analyzed samples for $\mathrm{FB}_{1}$, with no detection for $\mathrm{FB}_{2}$. Low contamination levels were also reported by Truckess et al. [40]: $70 \mu \mathrm{g} \mathrm{kg}^{-1}$ for canned maize and $98 \mu \mathrm{g} \mathrm{kg}^{-1}$ for frozen maize; Pittet et al. [39] reported $70 \mu \mathrm{g} \mathrm{kg}^{-1}$ for $\mathrm{FB}_{1}$ and nd for $\mathrm{FB}_{2}$ in Switzerland; and Piñeiro et al. [38] reported $65 \mu \mathrm{g} \mathrm{kg}^{-1}$ for $\mathrm{FB}_{1}$ and nd for $\mathrm{FB}_{2}$, in Uruguay.

The comparison between countries in Europe is somehow difficult regarding the few recent reports of contamination by fumonisins in these kinds of goods.

One maize flour sample exceeded the recommended limit of $2,000 \mu \mathrm{g} \mathrm{kg}^{-1}$ proposed by the European Mycotoxin Awareness Network [41], and two maize samples exceeded the maximum allowable concentration of $\mathrm{FB}_{1}+\mathrm{FB}_{2}$ established by Switzerland, $1,000 \mu \mathrm{g} \mathrm{kg}$ [42].

For maize samples and maize products collected in a central zone of Portugal, the average sample contamination of $\mathrm{FB}_{1}+\mathrm{FB}_{2}$ was $303 \mu \mathrm{g} \mathrm{kg}$. Assuming that the estimation of average daily intake of maize in the Portuguese population is $27.9 \mathrm{~g}$ per person per day [43] and that an adult body weights $60 \mathrm{~kg}$, the estimated daily intake (EDI) of fumonisins in this study was $0.14 \mathrm{\mu g} \mathrm{kg}^{-1}$ body weight per day. These values are lower than the $2 \mu \mathrm{g} \mathrm{kg}^{-1}$ established by Commission Regulation (EC) No 856/2005[44].

According to data from Portuguese Food Balance, maize consumption in 2003 reached $10.19 \mathrm{~kg}$ per person per year, which means $27.90 \mathrm{~g}$ per person per day, second place in the EU rank of total consumption of cereals [43]. Accepting this, the daily intake would reach, on average, $0.14 \mu \mathrm{g} \mathrm{kg}^{-1}$ body weight per day or $0.98 \mu \mathrm{g} \mathrm{kg}^{-1}$ body weight per week, a close value $(70 \%)$ to the estimated total intake of $\mathrm{FB}_{1}$ in the European diet, $1.4 \mu \mathrm{g} \mathrm{kg}-1$ body weight per week [45]. The provisional maximum tolerable daily intake (PMTDI) for $\mathrm{FB}_{1}+\mathrm{FB}_{2}$ is $2 \mu \mathrm{g} \mathrm{kg}$ body weight per day. This data was not overlapped for the most contaminated sample, representing $47.1 \%$ of the PMTDI reported by EMAN [41], but represents $118 \%$ when TDI of $0.8 \mu \mathrm{g} \mathrm{kg}^{-1}$ body weight per day, proposed by Gelderblom et al. [46] is chosen as reference.

\section{Conclusions}

Extraction with methanol/water, centrifugation, and dilution with PBS allows the supernatant to be applied onto an IAC column, making it possible to achieve low limits of detection. Stability of NDA fluorescent derivatives over- whelmed the time-dependent degradation presented by OPA. This optimized analytical methodology provides good results in terms of accuracy, repeatability, intermediate precision and sensitivity, and has been shown to be reliable for determination of $\mathrm{FB}_{1}$ and $\mathrm{FB}_{2}$ in maize and maize products presenting limits of detection of $20 \mu \mathrm{g} \mathrm{kg}^{-1}$ and $15 \mu \mathrm{g} \mathrm{kg}^{-1}$ for $\mathrm{FB}_{1}$ and $\mathrm{FB}_{2}$, respectively.

The application of the procedure to 31 samples from the central Portugal has demonstrated that $45 \%$ of the samples were contaminated, $\mathrm{FB}_{1}$ contamination levels were higher than $\mathrm{FB}_{2}$, and some maize samples and maize flour exceed the recommended limits.

None of the analyzed samples exceeded the provisional maximum tolerable daily intake. The estimated daily intake demonstrated that FBs do not represent a real concern for consumers.

Acknowledgements This work was carried out with the financial support, which is gratefully acknowledged, from the FCT and FEDER/ POCTI. The authors are also gratefully recognized to FCT for a $\mathrm{PhD}$ fellowship granted to Liliana Silva.

\section{References}

1. Lerda D, Bistoni BM, Peralta N, Ychari S, Vazquez M, Bosio G (2005) Food Chem Toxicol 43:691-698

2. Thiel PG, Marasas WFO, Sydenham EW, Shephard GS, Gelderblom WCA., Nieuwenhuis JJ (1991) Appl Environ Microbiol 57:1089-1093

3. Labuda R, Tanèinova D, Hudec K (2003) Ann Agric Environ Med 10:61-66

4. Stack ME (1998) J AOAC Int 81:737-740

5. IARC (2002) IARC monographs on the evaluation of carcinogenic risks to humans, Lyon, France, 82:301-366

6. Bolger M, Coker RD, DiNovi M, Gaylor D, Gelderblom W, Olsen M, Paster N, Riley RT, Shephard G, Speijers (2001) WHO food additives series 47 , FAO food and nutrition paper 74; prepared by the 56th meeting of the Joint FAO/WHO Expert Committee on Food Additives (JECFA); WHO: Geneva, Switzerland, pp 103-279. Available at http://www.inchem.org/ documents/jecfa/jecmono/v47je03.htm\#6.0. Accessed October 2005

7. Zinedine A, Brera C, Elakhdari S, Catano C, Debegnach F, Angelini S, Santis BD, Faid M, Benlemlih M, Minardi V, Miraglia M (2005) Food Control (in press)

8. Bittencourt ABF, Oliveira CAF, Dilkin P, Corrêa B (2005) Food Control 16:117-120

9. Bankole SA, Mabekoje OO (2004) Food Addit Contam 21:251-255

10. Sydenham EW, Gelderblom WCA, Thiel PG, Marasas WFO (1990) J Agric Food Chem 38:285-290

11. Scudamore KA, Patel S (2000) Food Addit Contam 17:407-416

12. FAO (2003) Available at http://nue.okstate.edu/Crop Information/ World Wheat Production.htm. Accessed June 2005

13. Doko MB, Rapior S, Visconti A, Schjøth JE (1995) J Agric Chem 43:429-434

14. Duncan K, Kruger S, Zabe N, Kohn B, Prioli R (1998) J Chromatogr A $815: 41-47$

15. Lino CM, Silva LJG, Pena AS. Química Nova (in press)

16. Scudamore KA, Nawaz S, Hetmanski MT (1997) Food Addit Contam 14:175-186

17. Cortez-Rocha MO, Ramírez-Astudillo WR, Sánchez-Mariñez RI, Rosas-Burgos EC, Wong-Corral FJ, Borboa-Flores J, Castillón-Campaña LG, Tequida-Meneses M (2003) Bull Environ Contam Toxicol 70:668-673 
18. Voss KA, Riley RT, Norred WP, Bacon CW, Meredith FI, Howard PC, Plattner RD, Collins TFX, Hansen DK, Porter JK (2001) Environ Health Perspectives 109 (suppl 2):259-266

19. Lombaert GA, Pellaers P, Roscoe V, Mankotia M, Neil R, Scott PM (2003) Food Addit Contam 20:494-504

20. Dombrink-Kurtzman MA, Dvorak TJ (1999) J Agric Food Chem 47:622-627

21. Castro MFPM, Shephard GS, Sewram V, Vicente E, Mendonça TA, Jordan AC (2004) Food Addit Contam 21:693-699

22. Kim E-K, Scott PM, Lau BP-Y (2003) Food Addit Contam 20:161-169

23. Scott PM, Lawrence GA (1995) J Food Protection 58:1379-1382

24. Scott PM, Lawrence GA (1992) J AOAC Int 75:829-834

25. Molinié A, Faucet V, Castegnaro M, Pfohl-Leskowicz A (2005) Food Chem 92:391-400

26. Cirillo T, Ritieni A, Galvano F, Cocchieri RA (2003) Food Addit Contam 20:566-571

27. Plattner RD (1999) Nat Toxins 7:365-370

28. Musser SM, PlattnerRD(1997)J Agric Food Chem 45:1169-1173

29. Bennett GA, Richard JL (1994) J AOAC Int 77:501-506

30. Shephard GS (1998) J Chromatogr A 815:31-39

31. Williams LD, Meredith FI, Riley RT (2004) J Chromatogr B 806:311-314

32. Chu FS, Li GY (1994) Appl Environ Microbiol 60:847-852

33. Sydenham EW, Shephard GS, Thiel PG (1992) J AOAC Int 75:313-318
34. Solfrizzo M, Girolamo A, Visconti A (2001) Food Addit Contam 18:227-235

35. Domijan AM, Peraica M, Jurjevic Z, Ivic D, Cvjetkovic B (2005) Food Addit Contam 22:677-680

36. Castellá G, Bragulat MR, Cabañes FJ (1999) J Agric Food Chem 47:4707-4710

37. Broggi LE, Resnik SL, Pacin AM, González HHL, Cano G, Taglieri D (2002) Food Addit Contam 19:465-469

38. Piñeiro MS, Silva GE, Scott PM, Lawrence GA, Stack ME (1997) J AOAC Int 80:825-828

39. Pittet A, Parisod V, Schellenberg M (1992) J Agric Food Chem 40:1352-1354

40. Truckess MW, Stack ME, Allen S, Barrion N (1995) J AOAC Int 78:705-710

41. EMAN (2000). European Mycotoxin Awareness Network. Available at http://www.mycotoxins.org. Accessed April 2004

42. Shephard GS, Marasas WFO, Leggott NL, Yasdanpanah H, Rahimian H, Safavi N (2000) J Agric Food Chem 48:1860-1864

43. INE (2004) Available at http://www.ine.pt. Accessed June 2005

44. Commission Regulation (EC) $N^{\circ} 856 / 2005$. Official Journal of European Communities $n^{\circ} \mathrm{L} 143$, June 7 2005, pp 0003-0008

45. Soriano JM, Dragacci S (2004) Food Res Int 37:367-374

46. Gelderblom WCA, Marasas WF, Vleggaar R, Thiel PG, Cawood ME (1992) Mycopathologia 117:11-16 